\title{
The effects of diet on some metabolic enzymes in the small intestinal mucosa during lactation in the rat
}

\author{
BY MAUREEN F. PALMER* AND B. A. ROLLS \\ National Institute for Research in Dairying, Shinfield, Reading RG2 $9 A T$
}

(Received 2I May I979-Accepted 25 January 1980)

\begin{abstract}
I. Five groups of rats were investigated: (a) unmated rats allowed free access to a commercial stock rodent diet (NP group); (b) rats in the second week of lactation allowed free access to the stock diet; (c) rats in the second week of lactation allowed only that amount of the stock diet eaten by the NP group; (d) rats in the second week of lactation allowed that amount of the stock diet eaten by the NP group and in addition free access to a high-energy, protein-free supplement; (e) rats in the second week of lactation allowed that amount of the stock diet eaten by the NP group and in addition free access to a protein supplement.

2. The weight and length of the small intestine, the mucosal content of protein and of DNA and the mucosal activities of alkaline phosphatase $(E C$ 3.1.3.1), acid phosphatase $(E C$ 3.1.3.2), isocitric dehydrogenase $\left(\mathrm{NADP}^{+}\right)(E C$ I I I I I . 42) and glucose-6-phosphatase $(E C$ 3. I .3.9) were measured in individual animals.

3. For the factors investigated it was, with few exceptions, found that: there were markedly higher values in lactating animals allowed unrestricted access to food than in unmated animals; in restricted lactating animals the values were considerably lower than in unrestricted lactating rats and often similar to those in unmated animals; supplements of dietary energy restored none or only a proportion of the increases usually found in lactation but a protein supplement restored most or all these increases. Reasons for departure from this general picture on the part of some factors are discussed.

4. The results presented here support the view that changes found in lactation are hormonally induced but governed by nutrient availability, that protein is the important nutrient raw material but that dietary energy can support some changes probably by a 'protein-sparing' effect. Some changes appear to be less susceptible to the effects of dietary restriction, whether of protein or total energy. It is suggested that the additional nutrients eaten by unrestricted lactating rats permit the development of more, but less mature, enterocytes.
\end{abstract}

Pregnancy and lactation are associated with changes in several extrareproductive organs and some of these have been reviewed comprehensively by Fell (1977) and briefly by Rolls et al. (1979). Recent work in this laboratory on changes in organ size and in digestive and metabolic enzymes in the pancreas and small intestine (Rolls, 1975; Rolls et al. I979; Palmer \& Rolls, 1980) has led us to suggest that the organ enlargements and hypersecretion of pregnancy and lactation may be initiated and mediated by hormonal mechanisms but that the timing and magnitude of these changes may be controlled at least partly by nutrient availability. It has been shown with rats that dietary restriction may abolish some or all the effects of pregnancy and lactation on intestinal enlargement (Campbell \& Fell, 1963) and the secretory response of isolated islets of Langerhans (Green \& Taylor, 1974).

The aim of the work described here was to investigate the role of nutrient availability by testing the effects of different forms of dietary restriction during lactation on the morphology and metabolic enzyme content of the small intestine. The four enzymes studied were chosen as representing different locations in the cell and were known (Palmer \& Rolls, 1980) to be significantly higher in lactating than in unmated rats: alkaline phosphatase (EC 3.1.3.I), acid phosphatase (EC 3.I.3.2), isocitric dehydrogenase (NADP $\left.{ }^{+}\right)(E C$ I.I.I.42) and glucose-6-phosphatase ( $E C$ 3. I .3.9).

The enzymes were chosen as representing different locations within the cell. Alkaline

* Present address: Department of Physiology, Queen Elizabeth College, Campden Hill Road, London W8 7 AH. 
phosphatase is located in the brush border, acid phosphatase in the lysosomes and glucose6-phosphatase in the endoplasmic reticulum. NADP-dependent isocitric dehydrogenase activity is located in the mitochondria and cytosol and may be two separate enzymes or one distributed between the two. Their exact metabolic roles are the subjects of continuing investigation. Alkaline phosphatase may be associated with the transport of nutrients across and the transfer of energy within the microvillar membrane (Fernley, 1971), and acid phosphatase with the provision of energy for organelle destruction. There is disagreement on whether the respiratory-chain-linked oxidation of citrate under normal conditions proceeds through the NADP-linked enzyme or through the NAD-dependent enzyme (isocitrate dehydrogenase (NAD ${ }^{+}$);EC I.1.I.41) while the former functions under conditions of high energy demand or in biosynthetic or control processes (Garland, I968; Stein et al. 1967). Smith \& Plaut (1979) have discussed the relative importance of the two enzymes to citric acid cycle oxidation. The major sites of glucose-6-phosphatase activity are in liver, small intestine and kidney (Colilla et al. 1975), thus allowing these tissues to produce glucose for utilization or addition to the blood. In liver and kidney glucose-6phosphatase functions in the terminal stage of gluconeogensis but the absence of some enzymes from this pathway in the intestine suggests a different role, perhaps that of insulininsensitive glucose transport (see Lygre \& Nordlie, I968).

\section{MATERIALS AND METHODS}

\section{Chemicals}

Laboratory chemicals were of Analar grade. Enzyme substrates and other biochemicals were obtained from Sigma (London) Chemical Co., Poole, Dorset, except for glucose-6phosphoric acid, dipotassium salt and Folin-Ciucalteu reagent, which came from BDH Ltd, Poole, Dorset.

\section{Diets}

All the rats were reared and fed until parturition with a commercial stock laboratory diet (Spratts Laboratory Diet I). The protein-free supplement contained $(\mathrm{g} / \mathrm{kg}):$ maize starch 750, potato starch 100 , glucose 93.5 . The protein supplement contained $943.5 \mathrm{~g}$ casein $/ \mathrm{kg}$ (Calbiochem Ltd, Bishops Stortford, Herts). In addition both supplements contained $(\mathrm{g} / \mathrm{kg})$ : salt mixture 50 , vitamin mix 5 , choline chloride $\mathrm{I} \cdot 5$. The salt mixture provided (/kg diet): $\mathrm{CaCO}_{3} 3 \mathrm{~g}, \mathrm{Ca}_{3}\left(\mathrm{C}_{6} \mathrm{H}_{5} \mathrm{O}_{7}\right)_{2} \cdot 4 \mathrm{H}_{2} \mathrm{O} I 4 \mathrm{~g}, \mathrm{CaH}_{4}\left(\mathrm{PO}_{4}\right)_{2} \cdot \mathrm{H}_{2} \mathrm{O}$ IO g, $\mathrm{C}_{6} \mathrm{H}_{5} \mathrm{O}_{7} \mathrm{Fe} \cdot 5 \mathrm{H}_{2} \mathrm{O}$

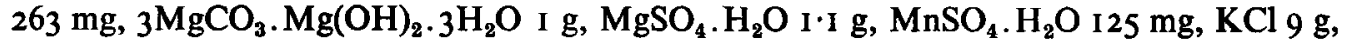
$\mathrm{Na}_{2} \mathrm{HPO}_{4} 8.25 \mathrm{~g}, \mathrm{NaCl}_{3} .2 \mathrm{~g}, \mathrm{AlNH}_{4}\left(\mathrm{SO}_{4}\right)_{2}$. $\mathrm{I}_{2} \mathrm{H}_{2} \mathrm{O} 4.5 \mathrm{mg}, \mathrm{CuSO}_{4} .5 \mathrm{H}_{2} \mathrm{O} 20 \mathrm{mg}, \mathrm{KIO}_{3}$ $\mathrm{I} \cdot 05 \mathrm{mg}, \quad \mathrm{NaF} 885 \mu \mathrm{g}, \mathrm{ZnSO}_{4} \cdot 7 \mathrm{H}_{2} \mathrm{O} 50.75 \mathrm{mg}, \mathrm{Na}_{2} \mathrm{~B}_{4} \mathrm{O}_{7} \cdot 3 \mathrm{H}_{2} \mathrm{O} 237 \mu \mathrm{g},\left(\mathrm{NH}_{4}\right)_{6} \mathrm{Mo}_{7} \mathrm{O}_{24}$. ${ }_{4} \mathrm{H}_{2} \mathrm{O} 73.5 \mu \mathrm{g}, \mathrm{Na}_{2} \mathrm{SeO}_{3} 88 \mu \mathrm{g}$. The vitamin mixture, which was made up in glucose, provided (/kg diet): biotin $490 \mu \mathrm{g}$, pteroylmonoglutamic acid $3.7 \mathrm{mg}$, thiamin hydrochloride $7.4 \mathrm{mg}$, pyridoxine hydrochloride $9.9 \mathrm{mg}$, riboflavin $4.8 \mathrm{mg}$, calcium pantothenate $37 \mathrm{mg}$, nicotinic acid $100 \mu \mathrm{g}$, retinol $2.13 \mathrm{mg}$, cholecalciferol $\mathrm{I} 3.5 \mu \mathrm{g}, \alpha$-tocopheryl acetate $12.6 \mathrm{mg}$, menaphthone $2.5 \mathrm{mg}$, cyanocobalamin $200 \mu \mathrm{g}$. Both dietary supplements were pelleted and air-dried at $40^{\circ}$.

\section{Animals}

Female Norwegian Hooded rats, aged 3-4 months, from the Institute colony were used. For lactating animals, the rats were mated at intervals and the date of parturition was noted. Litter size was adjusted to eight to ensure that the demands of lactation were as uniform as possible. Five groups of rats were studied in this experiment, litter-mates being distributed randomly among the groups. The first group contained unmated, non-pregnant rats allowed free access to the stock diet. Under these circumstances the average food intake was $19 \mathrm{~g} / \mathrm{d}$. The second group consisted of rats at the end of the second week of lactation, again allowed 
free access to the stock diet of which they are known to eat approximately $50-60 \mathrm{~g} / \mathrm{d}$. The third group of rats was, on parturition, given only that quantity of stock diet that nonpregnant rats would eat, $19 \mathrm{~g} / \mathrm{d}$. These rats were killed and samples were taken after $14 \mathrm{~d}$, that is, at the end of the second week of lactation. Dietary restriction was not introduced during pregnancy because of the known ability of rats to resorb the foetuses during times of food shortage. The other two groups were, on parturition, given $19 \mathrm{~g}$ stock diet/d at 09.00 hours and in addition were allowed free access from 14.00 to 09.00 hours on the following day to a dietary supplement of either the protein-free or the protein pellets. The amount of supplement eaten was not monitored to avoid yet further disturbance to the nursing females. These supplements contained vitamin and mineral additions to avoid the possibility that the effects of a change in a major dietary component might be masked by a shortage of accessory factors. Rats in the last two groups were also killed at the end of the second week of lactation.

At the same time of day, without any previous fasting, the rat was anaesthetized with diethyl ether, the whole small intestine was washed out with ice-cold isotonic saline $(9 \mathrm{~g}$ sodium chloride/l) and removed, and the rat was killed. The weight and length of the small intestine were determined and the mucosa was removed and homogenized by ultrasonic vibrations. Saline and saline- $n$-butanol extracts of the homogenate were prepared and stored at $-20^{\circ}$ until analysed.

\section{Analysis and measurement of enzyme activities}

The protein content of the gut mucosa was measured by the method of Lowry et al. (1951) using the Folin-Ciocalteu reagent and the DNA content was estimated by the SchmidtThannhauser procedure as outlined by Fleck \& Munro (1962) using Burton's modification of the diphenylamine method (Burton, 1956). The activity of isocitric dehydrogenase (NADP+) in the mucosa was estimated by a method adapted from Ochoa (1948). A 0.25 M-glycylglycine buffer, $\mathrm{pH} 7 \cdot 4$ was used rather than a glycine buffer. Portions of the saline homogenate were added to a freshly-prepared 'mixed substrate' of isocitric acid, NADP, buffer and activating manganese chloride and the change in extinction at $340 \mathrm{~m} \mu$ was monitored over a $70 \mathrm{~s}$ period. Estimation of multifunctional glucose-6-phosphatase was based on the method of Swanson (1955), except that a 0.01 M-EDTA buffer, pH 6.5 was used in place of the maleic acid buffer. After incubation of the saline homogenate and substrate, inorganic phosphate was measured by the method of Allen (1940) which is a slight modification of that of Fiske \& Subbarow (1925). Acid and alkaline phosphatases were estimated by the method of Brandenberger \& Hanson (I953), using a 0.000365 M-ocarboxyphenyl phosphate solution as a substrate and with Tris buffer replacing glycine buffer for the alkaline phosphatase. The saline extract was used for acid phosphatase determinations and the saline- $n$-butanol extract for the alkaline phosphatase.

\section{RESULTS}

It was found that even those lactating rats given only that food which unmated rats would have eaten, a condition that must be regarded as a moderately-severe dietary restriction, managed to rear their young successfully, although they lost weight, usually approximately $60 \mathrm{~g}$. It was found that those animals eating a mixed diet ate the stock diet in preference to the supplements and had usually finished their allowance of this food within $4-5 \mathrm{~h}$ of feeding. Hence staggering the feeding was probably unnecessary.

The values for the gut weight and length and the small intestinal mucosal content of protein and DNA are given in Table $\mathrm{I}$. The increases during lactation in gut weight, length and thickness (as measured by weight per unit length) and protein were comparable with 
Maureen F. Palmer and B. A. Rolls
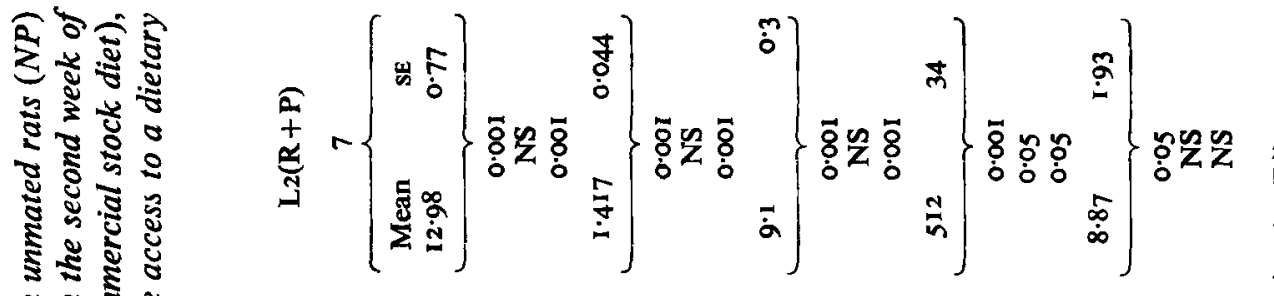

$\approx 5$ है

ठํ

รับ

จ

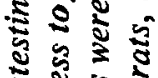

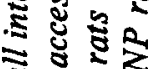

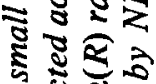

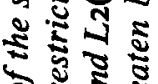

ชำ

ปิ

ปั่ ริ้

ए के

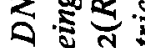

จุป ำ

वัฐ

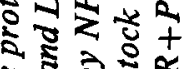

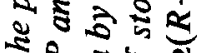

约

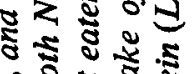

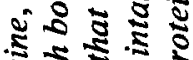

$2 \sqrt{2} 5.5$

武

ำ

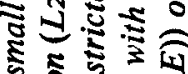

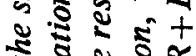

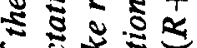

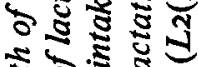
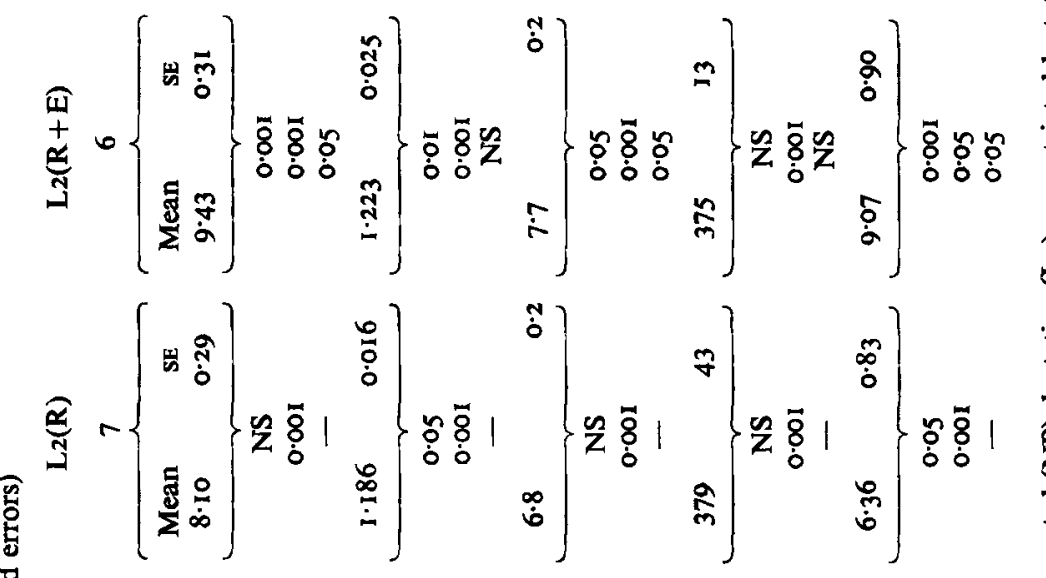

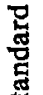

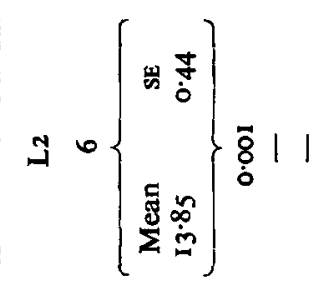

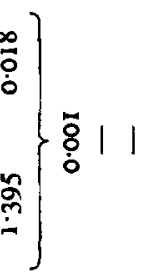

b)

\}

ơ

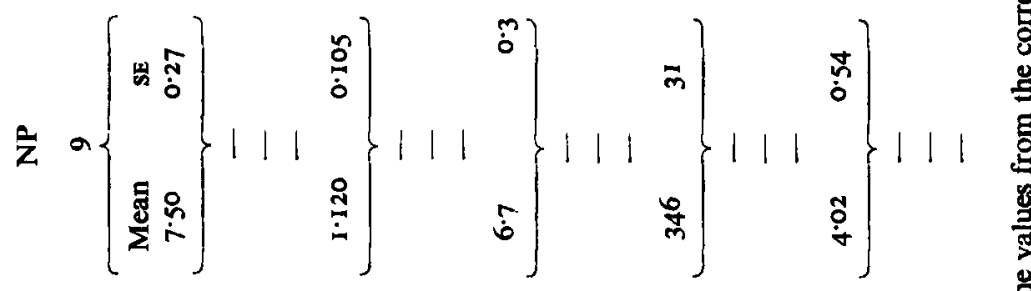

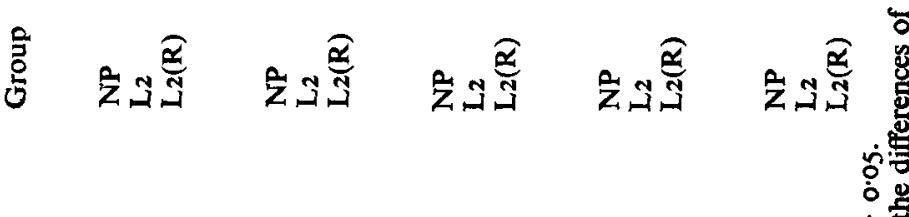

क्षे

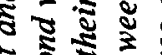

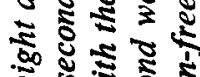

ปั

ㄷ. 525

40

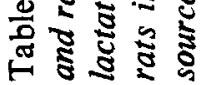

$\frac{5}{3}$ 


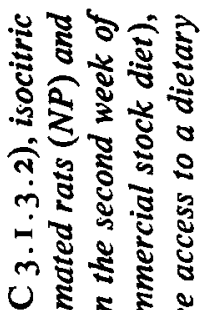

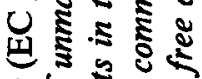

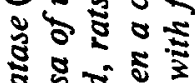

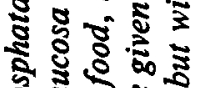

帘 2 :

ร)

ช.

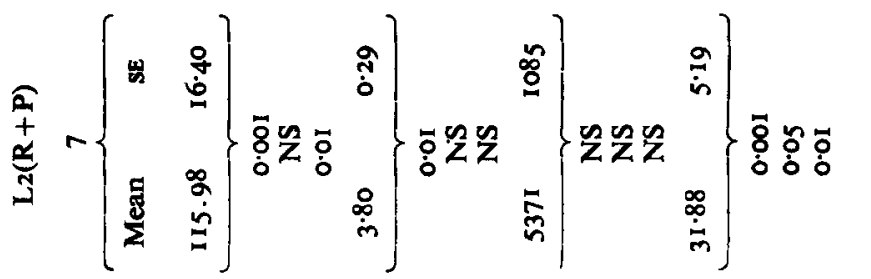

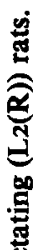

กิ

iิ

$\therefore$ ำ

$\dot{m}$ के है

西.

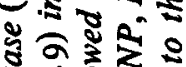

$\checkmark \dot{s} \leq \approx$

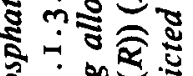

的为莡

记

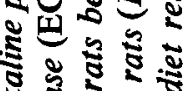

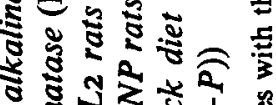

ช.

ชิ

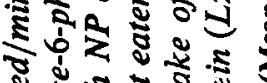

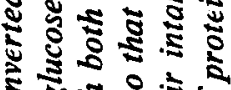

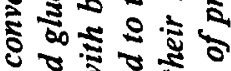

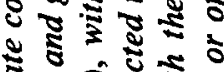

ชั้

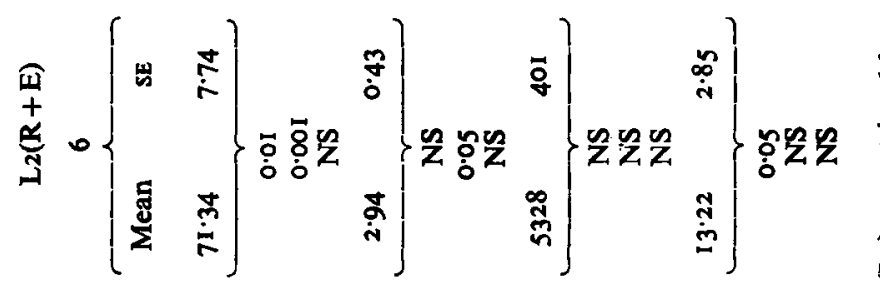

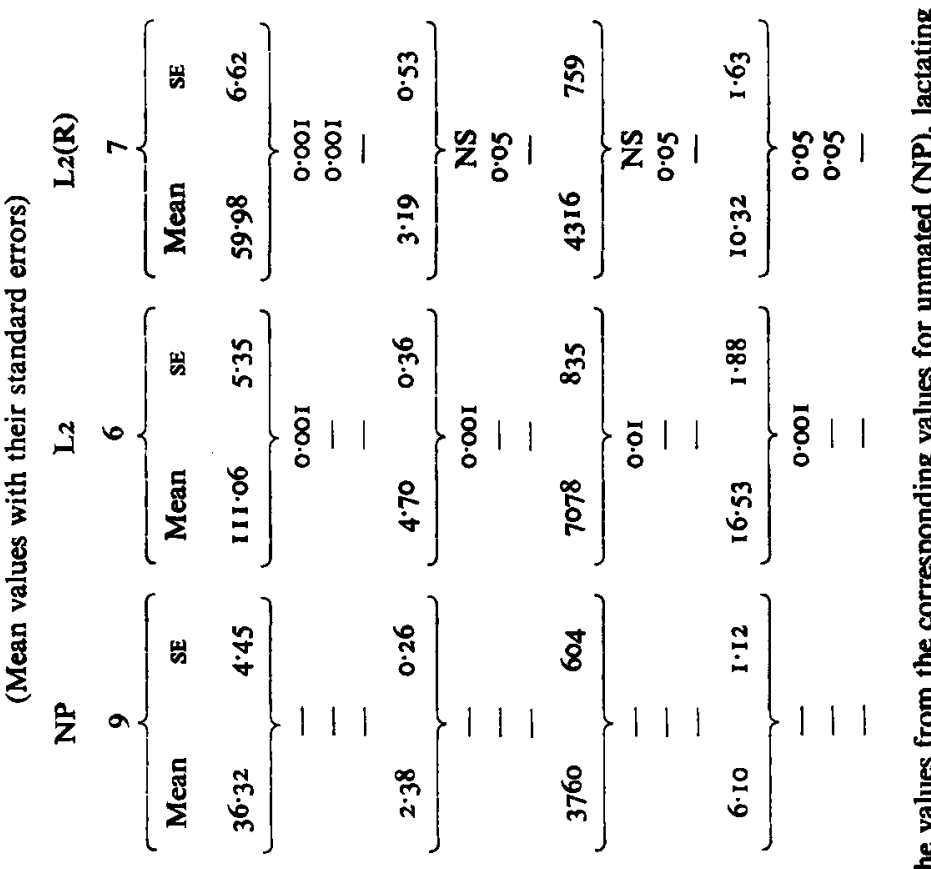

สิ

รี

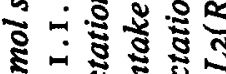

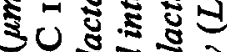

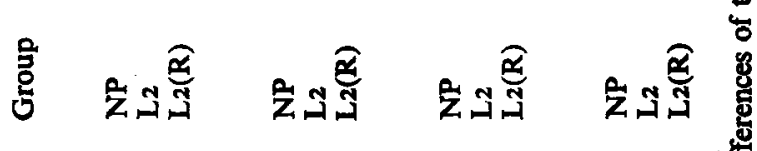

पु

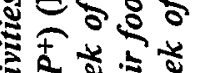

ํํำ

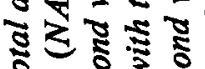

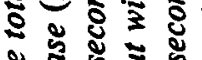

5

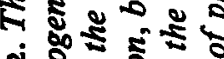

영 0.5

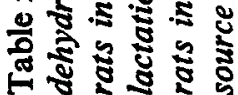
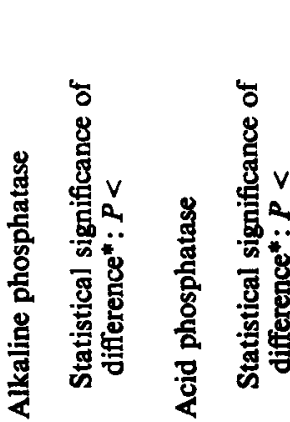

○े

要

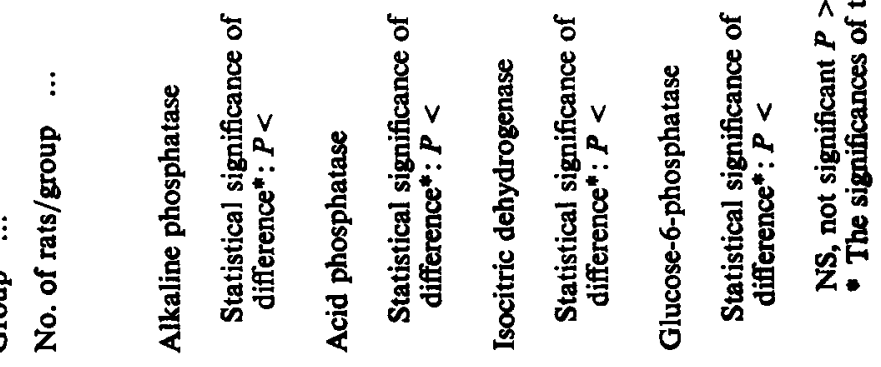


Maureen F. Palmer and B. A. Rolls

责 卷 है के ริฐ ๘ ปิ

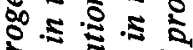

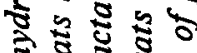
ริำ ชิ ํํำ

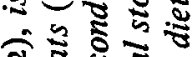

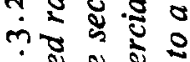

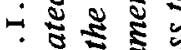
ชิ

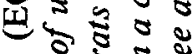
\%ำ s. s.

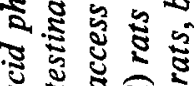
ป. ชู

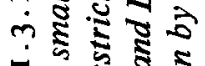
น่า

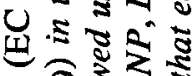
के z= รั sing so․․ำ

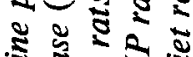
ริ งิ

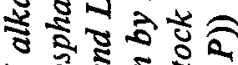

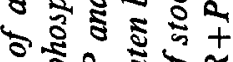

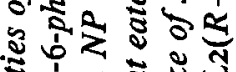

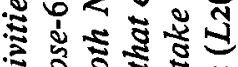

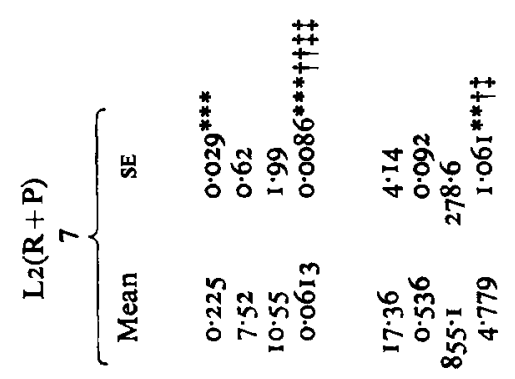

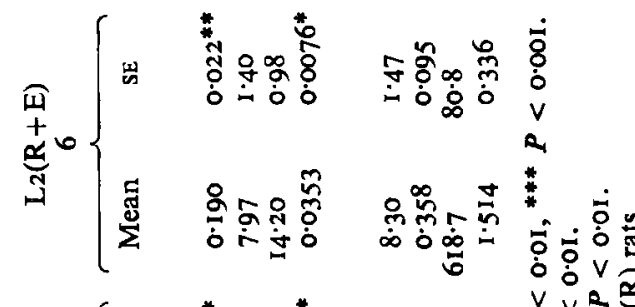

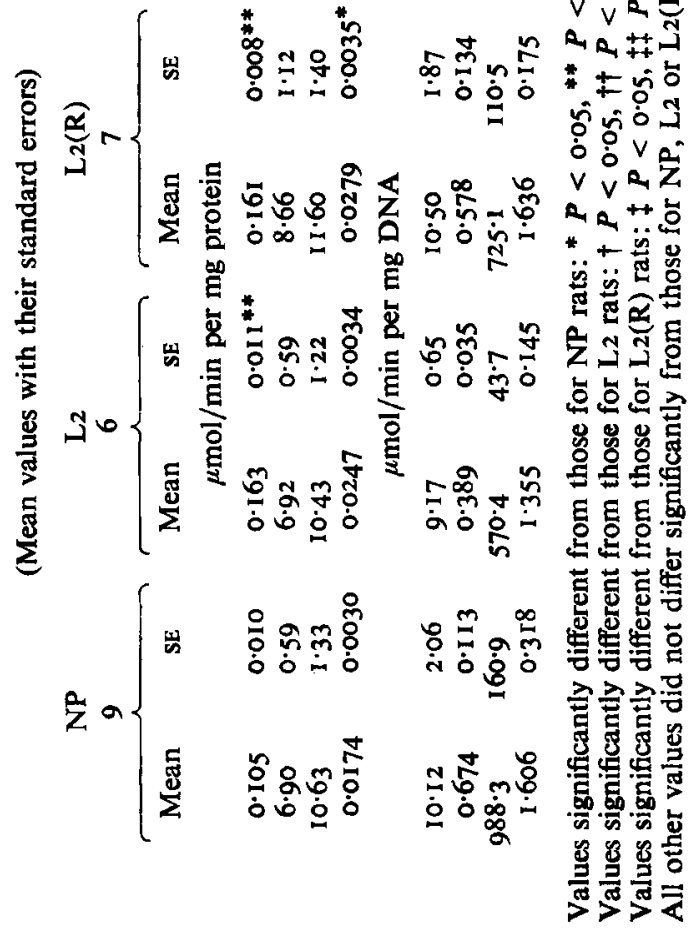
वे

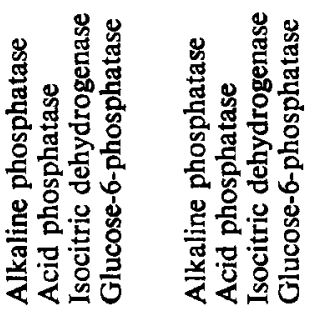
娄 จำ

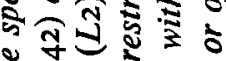
है म

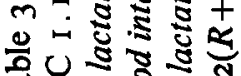

: 응
0
0
0

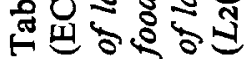


those reported before from this laboratory and elsewhere (Rolls, 1975; Fell, 1977). The DNA : protein value in the mucosa of unmated animals was similar to that found in many tissues but this increased considerably in lactation due to the striking increase in DNA. Similarly, although the value for protein : gut weight was essentially the same in unmated and lactating rats, that for DNA : gut weight was considerably higher in lactating animals.

The general picture that emerged with regard to dietary manipulation was that reducing the food intake of lactating rats to that of non-pregnant rats reduced or even abolished the increases associated with lactation (cf. Campbell \& Fell, 1963). The provision of additional dietary energy restored little or none of these increases, but additional dietary protein resulted in values much higher than those found in restricted rats, and often these values were not significantly different from those found in lactating rats allowed free access to the stock diet. Gut weight, thickness and mucosal protein content followed this general picture completely, but it can be seen (Table 1 ) that, for instance, dietary restriction failed to abolish completely the increases in gut length and mucosal DNA and that either supplement allowed the production of more mucosal DNA.

The total activities of the enzymes measured are given in Table 2 and the specific activities, expressed with respect to both protein and DNA, are in Table 3. Acid and alkaline phosphatase activities followed the pattern found in the factors listed in Table I : dietary restriction reduced or abolished the increases in activity found in lactation and these were restored partially or not at all by an energy supplement but largely or completely by additional protein. There are indications that either supplement was only partially effective in restoring isocitric dehydrogenase (NADP+) activity, but variability between animals made this point difficult to assess. Quite different behaviour was found in glucose-6-phosphatase activity. Dietary restriction during lactation only partly reduced the increase in activity normally found and much of this was restored by an energy supplement. However, a protein supplement produced a striking increase in activity, giving a total activity approximately twice that found in lactating rats eating the usual stock diet.

The specific activities were less subject to change, although in some instances variability may have obscured an effect. The specific activities per unit protein were either similar in unmated and lactating rats or slightly higher in the latter. Restricting the food intake of lactating animals did not alter specific activity. Either supplement produced increases, but the protein supplement caused large increases in alkaline phosphatase and glucose-6phosphatase activities. These increases arose since the energy supplement tended to produce small increases in enzyme activity and no increase in protein and the protein supplement produced marked increases in enzyme activity and, perhaps surprisingly, only a moderate increase in protein. An exception was acid phosphatase, whose specific activity remained almost unchanged by any treatment.

A slightly different picture emerged when specific activity per unit DNA was examined. The two groups of rats eating $19 \mathrm{~g}$ stock diet/d had similar specific activities whether they were non-pregnant or lactating. Lactating animals allowed unrestricted access to diet actually had lower specific activities, largely due to the large increases in mucosal DNA content. Lactating animals given the stock diet with supplements had specific activities that usually lay between the values for resiricted and unrestricted lactating rats. However, the protein supplement produced a large and significant increase in the specific activity of glucose-6-phosphatase. 


\section{DISCUSSION}

It was suggested by Rolls et al. (1979) that the organ enlargements and increased secretions observed during lactation in the rat and other animals may be explained by a mechanism in which hormonal changes provide the stimulus and the increased nutrient availability resulting from hyperphagia provides the raw materials for these changes. Many of the results from this work support such a mechanism. It seems clear that some of the changes in lactation were maintained, at least to some extent, preferentially or at the expense of others when nutrient supply was restricted. Moreover, if it is assumed that protein is the important raw material for structural enlargement and increased enzyme production, some functions appear to derive greater benefit from any 'protein-sparing' effects of giving the energy supplement. For instance, gut weight and DNA production could be considered 'favoured' changes whereas mucosal protein production has a lower priority. This would indicate that cell production is increased even during protein or energy restriction but that protein production does not mirror these changes, which implies that the cells may be smaller. The assumption made above that protein is the important nutrient for most changes is supported by the fact that the protein supplement was in general the more effective in restoring completely or to a greater extent the lactational changes produced by nutrient restriction.

The differences between non-pregnant and lactating rats allowed free access to food were similar to those found in earlier work. There were some differences in detail, largely in whether or not observed differences reached statistical significance. Even though this is not supported by statistical analysis, there were indications that the differences in enzyme activities between unmated and lactating rats may be dependent partly on external factors, particularly the age of mating. Perhaps the proportion of nutrients needed for somatic growth and adaption to lactation changes with age or the development of metabolic enzyme activities with maturation is accelerated or completed by impregnation. This possibility would have to be confirmed by further work.

The specific activities of enzymes per $\mathrm{mg}$ protein (see Table 3 ) were higher or similar for lactating as compared with non-pregnant animals. However, some enzymes had even higher activities in restricted lactating animals. This suggests that a change in the proportions of different enzymes synthesized may take place during lactation and further that under conditions of nutrient restriction amino acids are preferentially used for the production of some metabolic enzymes at the expense of other proteins. This hypothesis would be supported by the animals' weight loss. This may be analogous to the preferential maintenance of peptidases at the expense of saccharidases in the intestine of starved rats, possibly for metabolic purposes (Levin et al. 1962).

The specific activities per mg DNA showed a slightly different pattern: they tended to be approximately the same in unmated and restricted lactating rats but lower in lactating rats allowed free access to food. When lactating animals were given food to appetite food intake increased under hormonal influence and an increased number of enterocytes were produced, as indicated by the rise in DNA concentration. However, since the specific activities expressed with respect to DNA were reduced, the indication is that there was a higher proportion of immature cells on the villus. As the villi of lactating rats are longer, the arterial partial pressure of oxygen at the tips would be less than in non-pregnant animals and this would tend to increase migration rate, thus reducing cell maturity. A similar phenomenon has been observed in the absorptive function of the intestine: during lactation the total absorptive capacity increases even though the absorption per unit area of mucosa (and presumably per enterocyte) goes down (Craft, I970).

Alkaline phosphatase did not follow this pattern in specific activities although its total 
activity was quite typical. It is possible that as a brush-border enzyme it would not necessarily be proportional to the protein or DNA content of the whole cell. Since the brush border is developed fairly early during the migration of the cell from the crypt to the villus tip, the enzymes associated with it are probably developed at the same time and it is perhaps not surprising that the specific activity with respect to DNA does not change.

Most of the changes found in glucose-6-phosphatase activity were in line with those in the other factors. Feeding a protein supplement to lactating rats, however, resulted in total glucose-6-phosphatase activities twice those of rats eating the stock diet and increases even greater in specific activity. All these differences were statistically significant. If suggestions that the enzyme is involved in energy provision or transfer (Lygre \& Nordlie, 1968) are true it is difficult to explain its marked stimulation by increased dietary protein.

In summary, then, it may be argued that the lactational changes that have been stimulated hormonally require the additional nutrients from the increased food intake (which we have also suggested to be stimulated via gut hormones) for full development. Nutrient restriction reduces these changes, some more than others, but the reason why particular increases are preferentially maintained is not obvious from these results. As might be expected, the most important nutrient is protein (or amino acids), but additional energy has an appreciable effect, probably freeing dietary protein from being utilized as energy.

The authors thank Miss S. C. Woodley for technical assistance and Miss M. Tyler and her staff for care of the rats.

\section{REFERENCES}

Allen, R. J. L. (1940). Biochem. J. 34, 858.

Brandenberger, H. \& Hanson, R. (1953). Helv. chim. Acta 36, 900.

Burton, K. (1956). Biochem. J. 62, 315.

Campbell, R. M. \& Fell, B. F. (1963). J. Physiol., Lond. 171, 90.

Colilla, W., Jorgensen, R. A. \& Nordlie, R. C. (1975). Biochem. biophys. Acta 377, I 7.

Craft, I. L. (1970). Clin. Sci. 38, 287.

Fell, B. F. (1977). Rep. Rowett Inst. 33, 97.

Fernley, H. N. (1971). In The Enzymes, vol. 4, p. 421 [P. D. Boyer, editor]. New York: Academic Press.

Fiske, C. H. \& Subbarow, Y. (1925). J. biol. Chem. 66, 375.

Fleck, A. \& Munro, H. N. (1962). Biochim. biophys. Acta 55, 571.

Garland, P. B. (1968). In The Metabolic Roles of Citrate, p. 41 [T. W. Goodwin, editor]. London: Academic Press.

Green, I. C. \& Taylor, K. W. (1974). J. Endocr. 62, 137.

Levin, R. J., Newey, H. \& Smyth, D. H. (1962). J. Physiol., Lond. 164, 2 I P.

Lowry, O. H., Rosebrough, N. J., Farr, A. L. \& Randall, R. J. (195I). J. biol. Chem. I93, 265.

Lygre, D. G. \& Nordlie, R. C. (1968). Biochemistry, Easton 7, 3219.

Ochoa, S. (1948). J. biol. Chem. 174, 133.

Palmer, M. F. \& Rolls, B. A. (I980). J. Reprod. Fert. (In the Press).

Rolls, B. A. (1975). Br. J. Nutr. 33, I.

Rolls, B. 'A., Henschel, M. J. \& Palmer, M. F. (1979). Br. J. Nutr. 4I, 573.

Smith, C. M. \& Plaut, G. W. E. (1979). Eur. J. Biochem. 97, 283.

Stein, A. M., Stein, J. H. \& Kirkman, S. K. (1967). Biochemistry, Easton 6, 1370.

Swanson, M. A. (I955). Meth. Enzym. 2, 541. 